\title{
Human Platelet Lysate (HPL) as an Alternative Media Propagation of T47D Cells Line
}

\author{
Diani Mentari ${ }^{1 *}$, Relita Pebrina ${ }^{1}$, Diah Nurpratami $^{2}$ \\ ${ }^{1}$ Diploma of Study Programe Blood Bank Technology, STIKES Guna Bangsa Yogyakarta, Daerah Istimewa Yogyakarta, \\ Indonesia \\ ${ }^{2} \mathrm{PMI}$ Kota Yogyakarta, Daerah Istimewa Yogyakarta, Indonesia
}

\begin{abstract}
Fetal bovine serum (FBS) is a gold standard as a supplement to cell and tissue culture media. This is due to a large number of Growth Factor (GF) contained in FBS. However, the use of FBS is at risk of transferring endotoxins, prions, bacteria and viruses from animals to humans, so it is risky to be used on cell therapy. Human Platelet Lysate (HPL) is a medium that can be developed as an alternative cell growth medium. The advantage of HPL is that it does not contain aggregate platelets so it does not cause the cells to clot. This condition causes HPL to be used as a substitute medium replacing FBS for cell propagation. The use of HPL for cell propagation has been widely reported. However, the use of HPL in cancer cells has not been found. Thus, this study aims to see the effectiveness of HPL as a T47D cell culture medium. The study began with donor selection with criteria for the male sex, the blood type 0 , the age $\leq 35$ years. Furthermore, the Platelet Concentrate (PC) was processed into HPL then measured $\mathrm{pH}$, total protein and albumin levels. The cell viability was measured using the 3-(4,5-dimethylthiazol-2-yl)-2,5-dphenyl tetrazolium bromide (MTT) assay to determine the ability of cell proliferation when propagation using HPL. The doubling time test was carried out as in the cell proliferation test. However, the incubation was carried out for $24 \mathrm{~h}, 48 \mathrm{~h}$ and $72 \mathrm{~h}$ and the HPL concentration used was $5 \%$. The result shows that HPL $10 \%$ and $20 \%$ ability to increase proliferation better than the FBS $10 \%$. HPL with a $5 \%$ concentration ability to shortens the doubling time than FBS 10\% (doubling time is less than $19.94 \mathrm{~h}$ ). It this study, cell proliferation is influenced by the $\mathrm{pH}$ of HPL and total protein but not by the amount albumin.
\end{abstract}

Keywords: Human Platelet Lysate, Proliferation, T47D cell line, total protein, albumin.

\section{INTRODUCTION}

In vitro culture is one of the experiments used in various medical tests, one of which is anticancer. The development of cell culture has an impact on increasing the use of Fetal Bovine Serum (FBS). FBS is a supplement of cell culture medium containing essential nutrients such as protein, Growth Factor (GF), lipids, carbohydrates, fats, micronutrients and vitamins that are used to accelerate cell proliferation. It is estimated that the need for FBS reaches about 500,000 liters/year. It is indicated that more than $1,000,000$ cow fetuses must be "harvested". This is very contrary to animal

Submitted: December 10, 2019

Revised: February 8, 2020

Accepted: February 10, 2020

*Corresponding author: dianimentari@gmail.com 
welfare because to get FBS, the mother cow must be killed (euthanasia) and the fetus of the cow is left for 10-20 minutes before getting the blood. Also, the use of FBS can cause the risk of transferring endotoxins, bacteria and viruses from animals to humans (Brunne, et al., 2010; AVMA, 2013; Witzenedera, et al., 2013).

Platelet Concentrate (PC) is a blood component used for the treatment of thrombocytopenia patients due to bleeding or platelet function disorder (Goel, et al., 2015; Petraszko, et al., 2016). The ability of platelets to regenerate injured cells, blood vessel formation, mitogenesis (Durante, et al., 2013) and to regulate cell differentiation shows that platelets varied Growth Factor and protein contents (Hemeda, et $a l ., 2014)$. Thus, it can be used as an alternative to cell culture media.

Human Platelet Lysate (HPL) is a blood component made by repeatedly freezing-thawing PC. This is intended to lyse and dispose of platelet cell debris to get the growth factors. HPL also does not contain aggregate platelets so it does not cause cells to coagulate (Hemeda, et al., 2014; Mohammadi, et al., 2016). This is the reason why HPL can be used as a substitute media to replace FBS for cell culture.

The T47D cells are breast cancer cell lines isolated from breast cancer mammary ducts. The existence of p53 gene mutation in this cell line is the right model because $70 \%$ of breast cancers are caused by p53 gene mutation. P53 gene is a type of tumor suppressor gene. The mutation of this gene causes cells to undergo uncontrolled division (Foulkes, et al., 2007; Schafer, et al., 2000; Lies, et al., 2007; Varna, et al., 2011) The use of HPL for cell culture medium has been widely reported, especially for Mesenchymal Stromal Cells (MSC) (Lohman, et al., 2012; Fernandez-Rebollo, et al., 2017). However, there was no report on the use of HPL in the cancer cell line. Hence, this research is essential to see the effectiveness level of HPL for cell line propagation. HPL contains Vascular
Endothelial Growth Factor (VEGF), Insulin Growth Factor (IGF) and Transforming Growth Factor (TGF), which play a role in angiogenesis and inhibition of apoptosis (Durante, et al., 2013; Wen, et al., 2018). This condition is approaching in vivo condition, so it is expected to produce more accurate doubling time of cancer cells. The use of HPL together with anticancer compounds can lead to a more optimal dose.

\section{METHODS}

This study has been ethically approved by the Ethical Commission of Faculty of Medicine of Gadjah Mada University number: KE/FK/0346/ $\mathrm{EC} / 2019$. The research was conducted in the following stages:

\section{Donor Selection and Blood Screening}

Blood products are strongly influenced by the quality of donors. In this study, the sample used came from 4 donors. The donor selection process was carried out at The Indonesian Red Cross (PMI) Yogyakarta City. Hence, the prospective donors in this study must pass donor selection under Regulation of the Republic of Indonesia Minister of Health Regulation No. 91 of 2015. Also, these donors shall the following additional criteria which include: male, $\mathrm{O}$ blood type and less than 35 years old. Then, Donors according to the criteria drawn their blood to be put in a Triple Bags blood bags containing Citrate-Phosphate-Dextrose-Adenine (CPDA-1) (JMS PTE Ltd, Singapore). Whole blood was then screened for Hepatitis C, Hepatitis $\mathrm{B}$, Syphilis and human immunodeficiency virus (HIV) with ChemiluminescentImmuno Assay (Architech) method. Samples with negative results on Hepatitis C, Hepatitis B, Syphilis and HIV (Nonreactive), whole blood was processed into a $\mathrm{PC}$.

\section{The Making of Blood Component of PC}

Whole blood was centrifuged using Refigenerate Centrifuge blood bags (Kubota) 
at a speed of $380 \mathrm{~g}$ for 15 minutes at $22^{\circ} \mathrm{C}$, which would produce Packed Red Cell (PRC) and Platelet Rich Plasma (PRP). The separation process was improved using a plasma extractor (Novomatic, Gumpoldskirchen Austria). The PRP was then centrifuged again at a speed of $3000 \mathrm{~g}$ for 12 minutes at $22^{\circ} \mathrm{C}$. This process would produce a $\mathrm{PC}$ in a $50-70 \mathrm{~mL}$ volume bag. The PC was then stored in a plasma agitator (Helmer, Bergen Boulevard, Noblesville, USA) at a temperature of $20-24^{\circ} \mathrm{C}$ (Permenkes RI No. 91, 2015). The Platelet Concentrate was then stored for 3 days (sample code: A1 and A2) and 5 days (sample code: B1 and B2). In each storage, protein and albumin levels were measured. Besides, the $\mathrm{pH}$ was also measured using a $\mathrm{pH}$ meter (Ohaus)

\section{$\mathrm{pH}$ Measurement}

The $\mathrm{pH}$ level was measured before and after making of HPL. The sample was taken as much as $2 \mathrm{~mL}$ using a syringe and placed in a sterile glass tube. Measurement was conducted using a $\mathrm{pH}$ meter (Ohaus).

\section{Measurement of Protein Content}

A sample of $20 \mu \mathrm{L}$ was mixed with 1000 $\mu \mathrm{L}$ of mono reagent total FS protein (DiaSys, Holzheim, Germany). Then, it was incubated for 5 minutes at room temperature and had an absorbance measurement using a wavelength of $540 \mathrm{~nm}$. The total protein was calculated by comparing standard values.

\section{Measurement of Albumin Levels}

A sample of $10 \mu \mathrm{L}$ was mixed with 1000 $\mu \mathrm{L}$ of Albumin FS (DiaSys), then incubated for 10 minutes at room temperature and had an absorbance measurement using a wavelength of $540 \mathrm{~nm}$. Albumin levels were calculated by comparing standard values.

\section{The Making of HPL}

HPL was made using the PC freezingthawing method repeatedly. PC was frozen using plasma freezing and thawed using waterbath at $37^{\circ} \mathrm{C}$. The second and third freezing process was conducted using deep freezing of $-80^{\circ} \mathrm{C}$. The results of the freezing-thawing were then transferred to a sterile conical tube for centrifugation using $4000 \mathrm{rpm}$ for 15 minutes at room temperature. The supernatant was then removed and transferred to a sterile tube (carried out in Laminar Air Flow). The freezing-thawing process was carried out at the Research Laboratory, Faculty of Medicine, Universitas Islam Indonesia. HPL for each treatment was measured by $\mathrm{pH}$ meter, total protein content and albumin.

\section{Proliferation Test of HPL as a T47D Cell Culture Medium}

Proliferation test was carried out at Parasitology Laboratory, Faculty of Medicine, Universitas Gadjah Mada. The T47D cell stock was recultured in the flask and added with the Roswell Park Memorial Institute (RPMI) 1640 media which already contained $2 \%$ penicillin and streptomycin (penstrep) $0.5 \%$ fungizone and 10\% FBS. Furthermore, the cells were incubated using an incubator containing $5 \% \mathrm{CO}_{2}$ and temperature $37^{\circ} \mathrm{C}$. Confluent cells were removed from the media, washed by Phosphate Buffer Saline (PBS) and added with trypsin-EDTA to release cells from the flask. The cell suspension was accommodated in the conical then centrifuged to eliminate trypsin in a medium. Supernatant removed and the complete medium is added. The number of cells was calculated using a haemocytometer (Freshney, 2000). Proliferation cell analysis used the cell density of $10,000 / 100 \mu \mathrm{L}$ (microplate 96 well). The Cells that have been calculated for density then added RPMI medium which containing HPL $10 \%$, penstrep $2 \%$ and fungizone $0.5 \%$ dan the other cell treated using RPMI which containing HPL $20 \%$, penstrep $2 \%$ and fungizone $0.5 \%$. Control positive is RPMI with FBS $10 \%$, penstrep $2 \%$ and fungizone $0.5 \%$. Control negative is cell culture in RPMI medium only containing penstrep $2 \%$ and fungizone $0.5 \%$. 
The cell then incubated overnight in the incubator $\mathrm{CO}_{2}$, the temperature of $37^{\circ} \mathrm{C}$. After that, the medium in cell culture was removed, then added the PBS $100 \mu \mathrm{L}$ each well. The PBS was removed and then added $100 \mu \mathrm{L} /$ well 3-(4,5-dimethylthiazol2-yl)-2,5-dphenyl tetrazolium bromide (MTT) reagents. The cell incubated $2-4 \mathrm{~h}$ in the incubator $\mathrm{CO}_{2}$. After that add a stopper $100 \mu \mathrm{L} 10 \%$ SDS in 0.1 $\mathrm{N} \mathrm{HCl}$. Percentage of cell viability was calculated using MTT assay and its absorbance was read with ELISA reader $(530 \mathrm{~nm})$ and calculated using the following formula:

$\%$ of viable cells=(Absorbance of treatmentabsorbance of medium)/(absorbance of controlabsorbance of medium) $\times 100 \%$

\section{The Doubling Time Test for the Use of HPL on T47D Cell Culture Medium}

The doubling time test was carried out as in the cell proliferation test. However, the incubation was carried out for $24 \mathrm{~h}, 48 \mathrm{~h}$ and 72 $\mathrm{h}$ and the HPL concentration used was 5\%. Each incubation was calculated for its absorption value. The doubling time value was then analyzed by making a regression graph between cell viability and incubation time at each treatment.

\section{Statistical Analysis}

The data were analyzed using the SPSS 21 program. Previously, a normality test was performed. The Pearson correlation test was conducted to determine the relationship between variables (such as age and platelet count; platelet count with total protein; the proliferation cell with $\mathrm{pH}$, proliferation cell with total protein and albumin). The Pair T-Test was conducted to see the difference in $\mathrm{pH}$ values before and after HPL was made. One-Ways ANOVA and LSD test was performed to see whether there were differences in T47D cell proliferation grown on 10\% HPL and $20 \%$ HPL compared with 10\% FBS. The doubling time was analyzed by a regression equation between the number viability of cells with incubation time Multi ways-ANOVA and LSD test was performed to see the difference in the use of 5\% HPL in each sample with $10 \%$ FBS in the doubling time test.

\section{RESULTS}

\section{The Characteristics of Donors}

This stage is carried out to produce good quality of HPL because blood quality is influenced by donors. The characteristics of donors can be seen in Table 1. PC is taken from donors aged 20-30 years with a total of samples are 4. Platelet count can affect the quality of HPL, so a platelet count analysis is needed. Analysis correlation is needed to find out the relationship between age and platelet count. The analysis shows that age affected platelet count ( $p=0.04$ or $p<0.05$ ). The higher the age, the lower the platelet count produced $(r=-0.956)$. Table 1 shows that sample code B2 from donors aged 20 years had the highest platelet count, about $894(\times 103 \mu \mathrm{L})$.

Table 1. The Characteristics of Donors

\begin{tabular}{cccc}
\hline $\begin{array}{c}\text { Days of } \\
\text { storage }\end{array}$ & Sample Code & $\begin{array}{c}\text { Age of Donors } \\
\text { (Years old) }\end{array}$ & Platelet count $\left(\times 10^{3} \mu \mathrm{L}\right)$ \\
\hline \multirow{2}{*}{3} & A1 & 20 & 758 \\
& A2 & 30 & 343 \\
5 & B1 & 24 & 543 \\
& B2 & 20 & 894 \\
\hline
\end{tabular}

\section{The Total Protein and Albumin in HPL}

Protein is one of the macromolecules that are very important to regulate cell proliferation, so this study measured the total protein in each sample of HPL. The results of measurements of total protein and albumin can be seen in Figure 1. The range of total protein is $6.75-8.71 \mathrm{~g} / \mathrm{dL}$, the highest sample is code B1 $(8.71 \mathrm{~g} / \mathrm{dL})$ while the lowest is a sample with code A1 (6.75 g/dL). Pearson correlation analysis shows that the total protein was not affected by platelet count ( $p=0.714$ or $p>0.05$ ) and age $(p=0.806$ or $p>0.05)$.

Albumin is the most abundant protein in the blood. The results showed that the sample with code A2 had the lowest albumin content of $3.75 \mathrm{~g} /$ $\mathrm{dL}$ and the highest is sample B1 about $4.38 \mathrm{~g} / \mathrm{dL}$. Pearson correlation analysis show that the albumin was not affected by platelet count ( $p=0.605$ or $p>0.05)$, age $(p=0.435$ or $p>0.05)$ and total protein $(p=0.332$ or $p>0.05)$. 


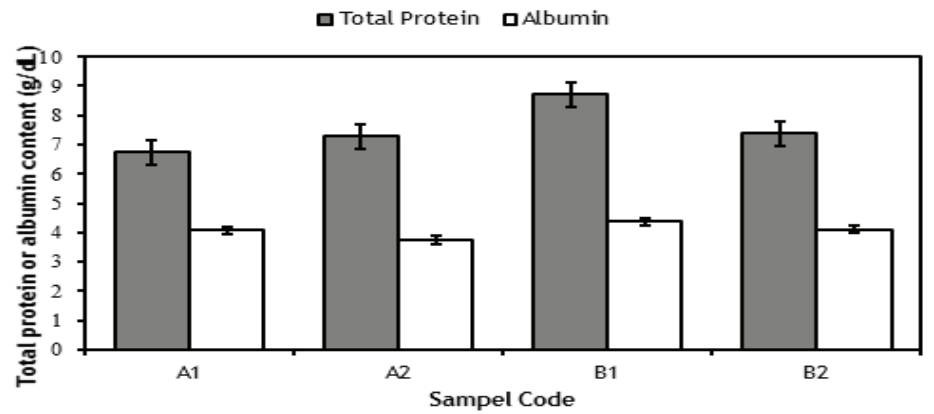

Figure 1. The Total protein and albumin content in HPL.

\section{The Value of $\mathrm{pH}$ in HPL}

The degree of acidity or $\mathrm{pH}$ was measured after making HPL. The measurement results show that each sample gives different values. There were also changes before and after the manufacture of HPL. In samples coded A1, A2 and B1, the $\mathrm{pH}$ before being processed into HPL were higher than after making HPL. However, this is different in samples with code $\mathrm{B} 2$, that is the $\mathrm{pH}$ before making HPL is lower than after making HPL. After making HPL, samples with code B1 had the lowest $\mathrm{pH}$ value of 7.1 and the highest B2 was 7.4 (Figure 2).

\section{The Proliferation of T47D in HPL Culture Medium}

In this study, T47D cell propagation media used HPL with concentrations of $10 \%$ and $20 \%$. Meanwhile, as a comparison (positive control), we used RPMI containing FBS of $10 \%$, penstrep $2 \%$ and fungizone $0.5 \%$ and cell control is $\mathrm{T} 47 \mathrm{D}$ propagation in RPMI medium, penstrep $2 \%$ and fungizone $0.5 \%$ without FBS or HPL. The results of T47D cell proliferation using cell culture media can be seen in Figure 3.

Figure 3 shows that T47D cell growth using HPL medium with a concentration of $10 \%$ or $20 \%$ can increase T47D cell proliferation better than FBS $10 \%$. Code sample B1-20 can increase proliferation 1.76 times greater than FBS $10 \%$, while the lowest is a sample with code B2-10 which is 1.07 times. LSD test results showed that samples A1-10, A2-10, A2-20, B1-20, B1-20, and B2-20 were significantly different in increasing cell proliferation compared with FBS $10 \%$. However, there were no significant differences between samples with codes A1-20 and B2-10 ( $p>0.05)$.

The proliferation of cells can be caused by several factors including $\mathrm{pH}$, the amount of protein and albumin. So to find out whether there is an influence, then the correlation analysis test is performed. The results of the analysis of Pearson correlation between cell proliferation and albumin show a value of $10 \%$ HPL $p=0.535$ and $20 \%$ HPL $p=0.426(p>0.05)$. It means no correlation.

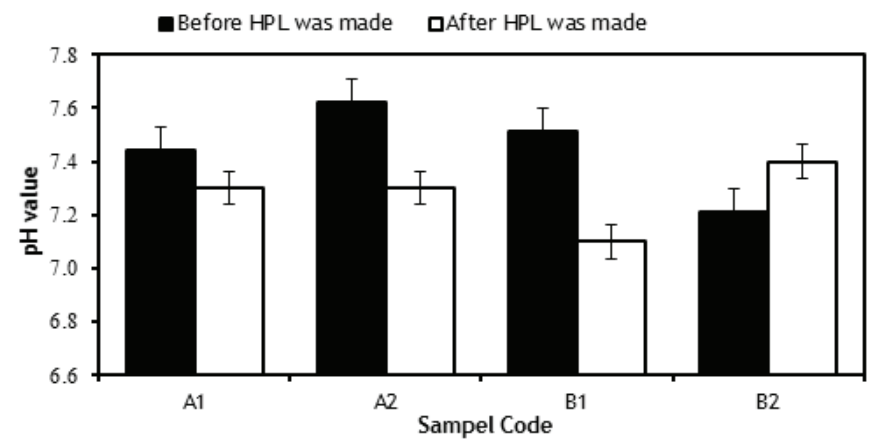

Figure 2. The values of $\mathrm{pH}$ before and after made of HPL. 


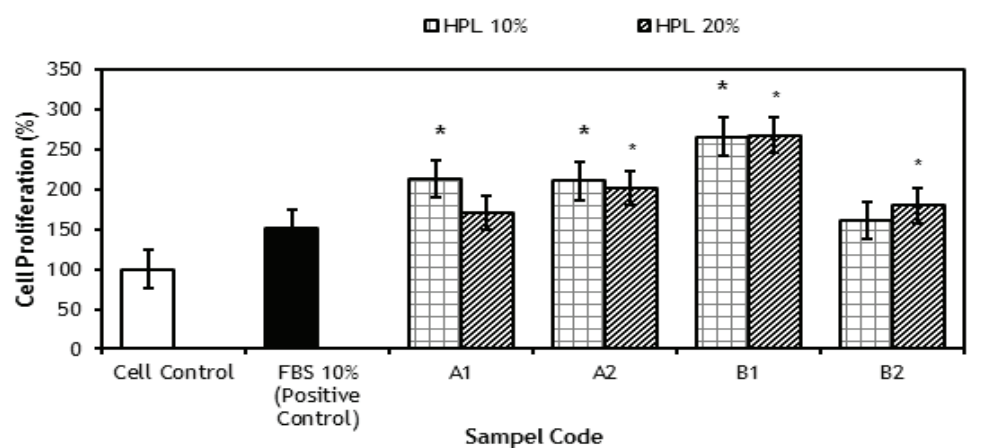

Figure 3. The percentage of cell growth using HPL $10 \%$ and HPL $20 \%$ on each storage day. *significant $(p<0.05)$.

\section{The Doubling Time of T47D Cells in HPL Cul- ture Medium}

The proliferation of cell activity was conducted by the doubling time test by incubating T47D cells using HPL for 0, 24, 48 and $72 \mathrm{~h}$. Each time, the incubation was measured the number of viable cells. The graph of the relationship between the number of lives with the duration of the incubation time is seen that there is an increasing number of cells while increasing the incubation time. However, HPL can increase T47D cell proliferation than propagation cells with FBS $10 \%$. The proliferation of T47D cell using HPL with various incubation times can be seen in Figure 4.

Table 2. The results for using $10 \% \mathrm{HPL}$ and $20 \% \mathrm{HPL}$ for the T47D cell proliferation medium for each treatment.

\begin{tabular}{|c|c|c|c|c|c|}
\hline \multirow{3}{*}{$\begin{array}{l}\text { Sample } \\
\text { Code }\end{array}$} & \multirow{3}{*}{$\begin{array}{c}\text { Concentration } \\
\text { of HPL }\end{array}$} & \multirow{3}{*}{ Mean \pm SD } & \multicolumn{2}{|c|}{ Comparison of each } & \multirow{3}{*}{$\begin{array}{l}\text { Independent } \\
\mathrm{T} \text {-Test }\end{array}$} \\
\hline & & & \multicolumn{2}{|c|}{ treatment with FBS $10 \%$} & \\
\hline & & & $\begin{array}{l}\text { Increased cell } \\
\text { proliferation }\end{array}$ & LSD test & \\
\hline \multirow{2}{*}{ A1 } & $10 \%$ & $208.47 \pm 9.26$ & 1.41 & $0.017^{*}$ & \multirow{2}{*}{0.471} \\
\hline & $20 \%$ & $191.67 \pm 35.39$ & 1.13 & 0.150 & \\
\hline \multirow{2}{*}{ A2 } & $10 \%$ & $205.89 \pm 6.45$ & 1.39 & $0.025^{*}$ & \multirow{2}{*}{0.138} \\
\hline & $20 \%$ & $226.88 \pm 18.58$ & 1.33 & $0.001^{*}$ & \\
\hline \multirow{2}{*}{ B1 } & $10 \%$ & $260.06 \pm 14.29$ & 1.76 & $0.000^{*}$ & \multirow{2}{*}{$0.037^{*}$} \\
\hline & $20 \%$ & $302.98 \pm 19.35$ & 1.77 & $0.000^{*}$ & \\
\hline \multirow{2}{*}{ B2 } & $10 \%$ & $157.90 \pm 9.20$ & 1.07 & 0.469 & \multirow{2}{*}{$0.042^{*}$} \\
\hline & $20 \%$ & $201.57 \pm 23.97$ & 1.19 & $0.044^{*}$ & \\
\hline
\end{tabular}

Note: $* p<0.05$ which means there is a significant difference Independent T-Test was conducted to see whether there was a difference in cell proliferation using concentration $10 \%$ HPL with 20\% HPL in each group. The results show that only samples with codes B1 and B2 have significant differences $(p<0.05)$.
Tabel 3. The Pearson correlation analysis between Cell Proliferation with others variable $(\mathrm{pH}$, Total protein and albumin).

\begin{tabular}{lcc}
\hline \multirow{2}{*}{ Variable } & \multicolumn{2}{c}{ Concentration of HPL } \\
\cline { 2 - 3 } & $10 \%$ & $20 \%$ \\
\hline Cell Proliferation-pH & $0.022^{*}$ & 0.087 \\
Cell Proliferation-Total Protein & 0.338 & $0.038^{*}$ \\
Cell Proliferation-Albumin & 0.475 & 0.574
\end{tabular}

Note: $* p<0.05$ which means there is a significant difference.

Figure 4 shows that in the $24^{\text {th }} \mathrm{h}$, the number of lives increased almost 2 times the number of initial cells, especially in samples with codes A1 and A2. Samples with A2 code can increase T47D cell proliferation greater than the others which are 1.22 times faster than FBS 10\%. Meanwhile samples with A1 code increase cell proliferation by 1.08 times. Samples B1 and B2 were able to increase cell proliferation 1.05 times and 1.09 times.

Table 4. The Doubling time of T47D cells in each treatment is sorted from the fastest time.

\begin{tabular}{|c|c|c|c|c|c|}
\hline \multirow{3}{*}{$\begin{array}{c}\text { Sample } \\
\text { Code }\end{array}$} & \multirow{3}{*}{$\begin{array}{c}\text { Concentration } \\
\text { of HPL }\end{array}$} & \multirow{3}{*}{ Mean \pm SD } & \multicolumn{2}{|c|}{ Comparison of each } & \multirow{3}{*}{$\begin{array}{c}\text { Independen } \\
\text { T-Test }\end{array}$} \\
\hline & & & treatment wi & FBS $10 \%$ & \\
\hline & & & $\begin{array}{l}\text { Increased cell } \\
\text { proliferation }\end{array}$ & LSD test & \\
\hline \multirow{2}{*}{ A1 } & $10 \%$ & $208.47 \pm 9.26$ & 1.41 & $0.017^{*}$ & \multirow{2}{*}{0.471} \\
\hline & $20 \%$ & $191.67 \pm 35.39$ & 1.13 & 0.150 & \\
\hline \multirow{2}{*}{ A2 } & $10 \%$ & $205.89 \pm 6.45$ & 1.39 & $0.025^{*}$ & \multirow{2}{*}{0.138} \\
\hline & $20 \%$ & $226.88 \pm 18.58$ & 1.33 & $0.001^{*}$ & \\
\hline \multirow{2}{*}{ B1 } & $10 \%$ & $260.06 \pm 14.29$ & 1.76 & $0.000^{*}$ & \multirow{2}{*}{$0.037^{*}$} \\
\hline & $20 \%$ & $302.98 \pm 19.35$ & 1.77 & $0.000^{*}$ & \\
\hline \multirow{2}{*}{ B2 } & $10 \%$ & $157.90 \pm 9.20$ & 1.07 & 0.469 & \multirow{2}{*}{$0.042^{*}$} \\
\hline & $20 \%$ & $201.57 \pm 23.97$ & 1.19 & $0.044^{*}$ & \\
\hline
\end{tabular}

Note: Significance value was obtained from the Anova Multi-Ways test and continued with the LSD test to see the significant use of 5\% HPL in each treatment compared to the $10 \%$ FBS. ${ }^{*} p<0.05$ which means there is a significant difference. 


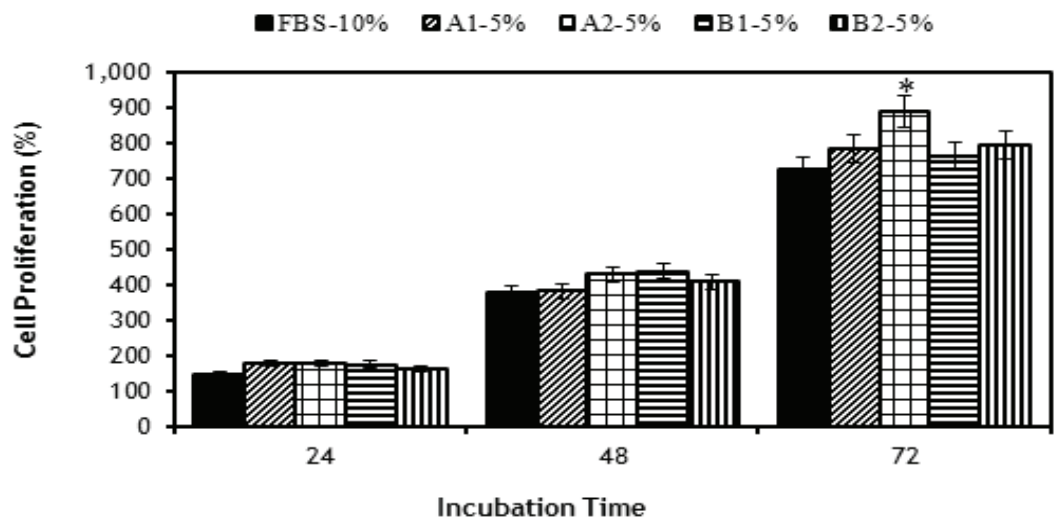

Figure 4. The Proliferation of T47D Cell line using alternative medium HPL concentration $5 \%$ measured in $0,24,48$ and $72 \mathrm{~h}$.

The doubling timeline is made with the regression equation between the numbers of lives with the length of time incubating to see the slope which is the kinetic parameter of the cellular parameters (Field, 1996 in Meiyanto, et al., 2003). The equation of regression and doubling time value can be seen in Table 4 .

\section{DISCUSSION}

HPL can be used as an alternative medium for cell culture in vitro. High quality platelets are needed for the production of HPL, which is greatly influenced by the condition of potential donors. In this study, PC samples were obtained from donors with a vulnerable age of 20-34 years ( $<35$ years), which aims to reduce the content of proteins that can cause aging. The effect of donor age was also reported on the use of HPL for the propagation of adipose tissue MSC (At-MSC) and Bone Marrow-MSC (BM-MSC). In those studies, HPL donors were grouped into 3 groups, $<35$ years old, 35-45 years old and $>45$ years old. The results showed that the use of HPL with age $<35$ years caused AT-MCS cell proliferation to be 1.4 times faster than the older donor ( $>45$ years). It is because the HPL of the donor produces a greater amount of susceptibility-associated beta-galactosidase (SA- $\beta$-gal), making it easier to experience information reduction, decreased function and ultimately death (Lohmann, et al., 2012; Biran, et al., 2017).

The Pearson correlation analysis results show that there is a relationship between age and platelet count $(p=0.04$ or $p<0.05)$ and the correlation is negative. Younger donors have more platelets. This is consistent with the research of Carlo, et al. (2014) that at the age of $<34$ years has a platelet count $>260 \times 109$ L for a female and $>240 \times 109 \mathrm{~L}$ for a male. However, the number of platelets has no effect on the number of growth factors produced (Weibrich, et al., 2002; Nugraha, et al., 2014). The study of Evanson, et al. (2014) states that at the age of $\leq 25$ years the number of Growth Factors is higher than the age $\geq$ of 25 years. Growth factors that are increasing are Epidermal Growth Factor (EGF), Insulin-like Growth Factor 1 (IGF-1), Platelet-Derived Growth Factor-AB (PDGP-AB), Platelet-Derived Growth Factor-BB (PDGF-BB) and Transforming Growth Factor Beta-1 (TGFP-1).

HPL is made using the PC freeze-thawing method repeatedly to lyse and dispose of platelet cell debris so that growth factors come out (Doucet, et al., 2005; Mohammadi, et al., 2016). Platelet Concentrate with a variety of storage times was first frozen using plasma freezing. Plasma freezing (a cooler containing glycerol) is widely 
owned by some The Indonesian Red Cross (PMI) because it is used to make the blood component of Fresh Frozen Plasma (FFP). The use of plasma freezing is a modification of an existing method (Hemeda, et al., 2014), usually for freezing HPL using deep freezing. Plasma freezing contains glycerol so that it can maintain protein structure when it is frozen (Pierce, 2003; Vagenende, et al., 2009) The thawing process uses waterbath at $37^{\circ} \mathrm{C}$. Freezing 2 and 3 is done using deep freezing $-80^{\circ} \mathrm{C}$. In this study, freezing-thawing was done 3 times. It is because freezing-thawing of 3 times can reduce the number of platelets 53\% compared to freezing-thawing of 2 times and 1 time, respectively $47 \%$ and $25 \%$. Also, freezing-thawing 3 times results in the amount of Vascular endothelial growth factor (VEGH), Platelet-derived growth factor - AA (PDGF AA), Epidermal growth factor (EGF) more than freezing-thawing which is done only 2 times (Baik, et al., 2014). The results of freezing-thawing are then centrifuged to separate the cell debris from the supernatant and HPL can be used as an alternative medium for cell growth.

In vitro culture, cell growth is one of the most important stages. In general, cell growth media use FBS additional supplements. This study used an alternative medium, which is HPL for T47D cell proliferation using concentrations of $10 \%$ and $20 \%$. The results of cell proliferation measurements show that the use of HPL can increase cell proliferation more than the use of $10 \%$ FBS. The use of low concentrations of HPL has also been reported by Cowper, et al. (2019) in Human Adipose-Derived Stromal/Stem Cells (ASC). HPL used were $0.1 \%, 0.33 \%, 0.75 \%$ and $1 \%$. The result is ASC cell proliferation using HPL concentrations of $0.75 \%$ and $1 \%$ can increase ASC proliferation more than $10 \%$ FBS. Meanwhile, the use of HPL concentrations of $0.1 \%$ and $0.33 \%$ proliferation is lower than $10 \%$ FBS. In this study, the use of $10 \%$ HPL and $20 \%$ give a different impact on each treatment for T47D cell proliferation. Sample code BI and B2 is a significant difference for T47D cell proliferation $(p<0.05)$. The sample with code $\mathrm{B} 1$ has the best proliferation ability compared to the other samples. This might be caused by higher protein content in B1.

In the doubling time test, the HPL concentration used was $5 \%$. It is intended to minimize cell death due to interference with the balance of the medium. The sample with code B1 has the best proliferation ability compared to the other samples. It is probably due to the total protein contained in HPL. Analysis of bivariate correlation between cell proliferation with HPL concentrations used with total protein yields a value of $p=0.038(p<0.05)$ at $20 \%$ HPL, while at $10 \%$ HPL a value of $p=0.338$ $(p>0.05)$. It means that cell proliferation in the use of $20 \%$ HPL is influenced by the total protein contained in the sample. It is appropriate because the sample having the highest total protein has the best ability to increase cell proliferation. Protein is a macromolecule that is used as a regulator of metabolism in cells. Proteins can induce proliferating cells by increasing the regulation of a cyclin so that the cells enter the S/synthesis phase (Cheng, et al., 2017).

Albumin is the most abundant protein in the blood. Based on in vitro, albumin inhibits lipid peroxidation and Reactive Oxygen Species (ROS) to keep cells from being damaged (Francis, 2010). However, in this study, cell proliferation of T47D was not influenced by albumin levels.

B1 sample produced the best cell proliferation compared to others, this might be caused by a higher protein content in B1. However, the doubling time test resulted in B1 has a long time compared to sample A2-5\%. Sample A2-5\% produces the fastest doubling time of $17.71 \mathrm{~h}$. It is likely to be influenced by changes in $\mathrm{pH}$. B1 code sample has the $\mathrm{pH}$ of 7.1 before being treated in the cell, the longer the storage (doubling time test takes $72 \mathrm{~h}$ ) is likely to cause changes in $\mathrm{pH}$. The $\mathrm{pH}$ value tends to be lower along with the longer storage time (Mentari, et al., 2020). The decrease in $\mathrm{pH}$ along with the length of time of storage may be influenced by the process of glycolysis, which 
is used for cell metabolism (Kholmukhamedov and Jobe, 2019). The final process of glycolysis is that dissolved $\mathrm{CO}_{2}$ compounds will cause conditions in the bag to become acidic, resulting in a decrease in $\mathrm{pH}$. The optimum $\mathrm{pH}$ value for some cell cultures is 7.4 .

\section{CONCLUSIONS}

HPL can be used as an alternative medium for the cell propagation of T47D, because it increases cell proliferation better than 10\% FBS. Increased cell proliferation will shorten the T47D cell doubling time. The proliferation of cell and doubling time are affected by $\mathrm{pH}$ and total protein.

\section{ACKNOWLEDGMENT}

This research was funded by Research Grant Ministry of Research and Technology 2019 (PDP) Contract Number: B/1435.37/L5/RA.00/2019 and LPPM STIKES Guna Bangsa Yogyakarta Contract number: 09/LPPM_GB/SK/IV/2019.

\section{REFERENCES}

AVMA, 2013, FBS and Animal Welfare, American Veterinary Medical Association AVMA Guidelines for the Euthanasia of Animals.

Baik, S.Y., Lim, Y.A., Kang, S.J., Ahn, S.H., Lee, W. G. and Kim, C.H., 2014, Effects of Platelet Lysate Preparations on the Proliferation of $\mathrm{HaCaT}$ Cells, Ann Lab Med, 34, 43-50.

Biran, A., Zada, L., Karam, P.A., Vadai, E., Roitman, L., Ovadya, Y., Porat, Z. and Krizhanovsky, V., 2017, Quantitative identification of senescent cells in aging and disease, Aging Cell, 16(4), 661-671.

Brunne, D., Frank, J., Appl, H., Schöffl, H., Pfaller, W. and Gstraunthaler, G., 2010, Serum-free Cell Culture: The Serum-free Media Interactive Online Database, Altex, 27(1), 53-62.

Carlo, L., Balduini and Noris, P., 2014, Platelet Count and Aging, Hematologica, 99 (6), 953-955.

Cheng, X.M., Xu, X., Liu, J., Mei, B., Fu, P. and Zhao, D., 2017, Panax ginseng total protein promotes proliferation and secretion of collagen in NIH/3T3 cells by activating extracellular signal-related kinase pathway, Journal of Ginseng Research, 41(3), 411-418.

Cowper, M., Frazier, T., hy, X., Curley, J.L., Ma, M.H., Mohiuddin, O.A., Dietrich, M., McCarthy, M., Bukowska, J. and Gimble, J.M., 2019, Human Platelet Lysate as a Functional Substitute for Fetal Bovine Serum in the Culture of Human Adipose Derived Stromal/Stem Cells, Cells., 8(7), 724

Doucet, C., Ernou, I., Zhang, Y., Llense, J-R., Begot, L., Holy, X. and Lataillade, J-J., 2005, Platelet lysates promote mesenchymal stemcell expansion: A safety substitute for animal serum in cell-based therapy applications, Journal of Cellular Physiology, 205(2), 228-236.

Durante, C., Agostini, F., Abbruzzese, L., Toffola, R.T., Zanolin, S., Suine, C. and Mazzucato, M., 2013, Growth factor release from platelet concentrates: analytic quantification and characterization for clinical applications, VoxSanguinis, 105(2), 129-136.

Evanson, R., Guyton, K. and Oliver, D.L., 2014, Gender and Age Differences in Growth Factor Concentrations From Platelet-Rich Plasma in Adults, Military Medicine, 179(7), 799.

Fernandez-Rebollo, E., Mentrup, D., Ebert R., Franzen, J., Abagnale, G., Sieben, T., Ostrowska, A. , Hoffmann, P., Roux, P-F., Rath, B., Goodhardt, M., Lemaitre, J-M., Bischof, O., Jakob, F. and Wagner, W., 2017, Human Platelet Lysate versus Fetal Calf Serum: These Supplements Do Not Select for Different Mesenchymal Stromal Cells, Scientific Reports, 7, 5131.

Foulkes, W,D., 2007, Gene p53 Master and Commander, The New England Jurnal of Medecine, 357(25), 2539-2541.

Francis, G.L., 2010, Albumin and mammalian cell culture: implications for biotechnology applica- 
tions, Cytotechnology, 62(1), 1-16.

Freshney, R,I., 2000, Culture of Animal Cells: A manual of Basic Techniques, $4^{\text {th }}$ Ed Wiley- Lies. Canada.

Goel, R., Ness, P.M., Takemoto, C.M., Krishnamurti, L., King, K.E. and Tobian, A.A., 2015, Platelet transfusions in platelet consumptive disorders are associated with arterial thrombosis and in -hospital mortality, Blood, 125(9), 1470-1476.

Hemeda, H., Giebel, B. and Wagner, W., 2014, Evaluation of human platelet lysate versus fetal bovine serum for culture of mesenchymal stromal cells, Cytotherapy, 16, 170-180.

Kholmukhamedov, A. and Jobe, S., 2019, Platelet respiration, Blood Advances, 3(4), 599-602.

Lohmann, M., Walenda, G, Hemeda, H., Joussen, S., Drescher, W., Jockenhoevel, S., Hutschenreuter, G., Zenke, M. and Wagner, W., 2012, Donor age of human platelet lysate affects proliferation and differentiation of mesenchymal stem cells, PLoS One, 7(5), e37839.

Meiyanto, E., Sismindari, Candra, L. and Moordiani, 2003, Efek Antiproliferatif Ekstrak Etanol Daun dan Kulit Batang Tanaman Cangkring (Erythrina fusca Lour.) terhadap Sel HeLa, Majalah Farmasi Indonesia, 14(3), 124-131.

Mentari, D., Pebrina, R. and Nurpratami, D., 2020, Effect Storage of pH, Glucose Level, LDH, Calcium and MPV as a Quality Indicator of Trombocyte Concentrate, Biomedika, Feb.12 (1).

Mohammadi, S., Nikbakht, M., Mohammadi, A,M., Panah, M.Z., Ostadali, M.R., Nasiri, H. and Ghavamzadeh, A., 2016, Human Platelet Lysate as a Xeno Free Alternative of Fetal Bovine Serum for the In Vitro Expansion of Human Mesenchymal Stromal Cells, International Journal of Hematology-Oncology and Stem Cell Reserach, 10(3), 161-172.

Nugraha, Y., Sari, P., Purwoko, R.Y., Luviah, E. and Adiwinata, J., 2014, Effect of lysed platelet count in platelet concentrates on various growth factor levels after freeze thaw cycles, International Journal of PharmTech Research., 6(7), 2036-2042.

Petraszko, T. and Zeller, M., 2016, Canadian Blood
Service: Platelet Transfution, Alloimunization and Management of Platelet Refractoriness. https://profedu.blood.ca/en/transfusion/ clinical-guide/platelet-transfusion-alloimmunization-and-management-platelet accessed on September $10^{\text {th }} 2019$.

Permenkes RI, 2015, Peraturan Menteri Kesehatan Republik Indonesia No. 91 tentang Standar Pelayanan Darah, Jakarta, Retrieved from https:// www.kemhan.go.id/itjen/wp-content/uploads/2017/03/bn36-2016.pdf

Pierce, 2003, Technical Resource. Protein stability and storage. http://wolfson.huji.ac.il/purification/PDF/StorageProteins/PIERCE_ProteinStorage.pdf, accces on 10th Sep 2019.

Regulation of the Minister of Health of the Republic of Indonesia Number 91 Year 2015 Concerning Blood Transfusion Service Standards.

Schafer, J.M., Lee, E.S., O'Regan, R.M., Yao, $\mathrm{K}$ and Jordan, V.C, 2000, Rapid Development of Tamoxifen-Stimulated Mutant p53 Breast Tumors (T47D) in Athymic Mice, Clin Cancer Res., 6, 4373-4380.

Vagenende, V., Yap, M.G and Trout, B,L., 2009, Mechanisms of protein stabilization and prevention of protein aggregation by glycerol, Biochemistry, 48(46), 11084-96.

Varna, M., Bousquet, G, Plassa, L-F., Bertheau, P. and Janin, A., 2011, TP53 Status and Response to Treatment in Breast Cancers, Journal of Biomedicine and Biotechnology, 2011(1), 1-9.

Weibrich, G., Kleis, W.K., Hafner, G, Hitzler, W.E, 2002, Growth factor levels in platelet-rich plasma and correlations with donor age, sex and platelet count, J Craniomaxillofac Surg, 30(2), 97-102.

Wen, Y.H., Lin, W.Y., Lin, C.J. and Sun, Y.C., 2018, Sustained or higher levels of growth factors in platelet-rich plasma during 7-day storage, Clinica Chimica Acta, 483, 89-93.

Witzenedera, K., Lindenmair, A., Gabriela, V. and Höllera, K., 2013, Human-Derived Alternatives to Fetal Bovine Serum in Cell Culture, Transfus Med Hemother, 40, 417-423. 